MATEC Web of Conferences 19,01039 (2014)

DOI: $10.1051 /$ matecconf/ 20141901039

(C) Owned by the authors, published by EDP Sciences, 2014

\title{
Electronic Database - Monitoring Tool and Quality Improvement of Supplied Electricity
}

\author{
Ksenia V. Ikonnikova ${ }^{1}$, Natalia E. Vaisblat, Igor S. Peremitin and Raisa N. Abramova \\ National Research Tomsk Polytechnic University, 634050 Tomsk, Russia
}

\begin{abstract}
The main aim of the research was to design an electronic database for transmission facilities (i.e. electricity supply network). The research task involves the following aspects: relevance of stated problem, development of information layers and corresponding attribute data through the geoinformation system and technology. The research showed definite results which were further incoporated into a graphically designed model of an electronic database, reflecting the information layers and the investigated range of primary consumers of future software product.
\end{abstract}

\section{Introduction}

Sustained socio-economic development of any region involves reliable electric power supply. In many cases, serious problems, not only for industries, but also for the community itself, could be power line breakdowns (transmission lines), especially, wire breakages. To prevent above-mentioned consequences, quality requirements in transmission facilities service were aggravated. According to RF Government Regulation № 160, dated 24.02.2009 [1], all networked organizations should provide safe service and maintenance of all fenced-off areas embracing different transmission facilities and quality conformance inspection.

\section{Research subject}

Nowadays, urgent ecological, economic and social problem-solving includes the DB project and electricity transmission line maintenance within total forest areas, which, in its turn, is stipulated by such factors as partial forest clearing for overhead transmission lines to ensure power supply continuity and service. According to the data presented by JSC "Interregional Distribution Grid Company of Siberia" ("IDGC of Siberia"JSC) the main average percentage of accidents are initiated by two two sources: mechanical damage to overhead transmission lines $(30 \%)$ and power line breakages as a result of timber felling during severe weather conditions (33\%) [2]. Most overhead transmission lines have been operating for more than 25 years (and even -50years). Monitoring data in tree growth and roading for the above-mentioned period are not available, whereas the legislative framework has greatly changed. Taking into account the complexity and multi-factor production problem solving, it is necessary to obtain accurate and reliable information, involving up-dated information and territorial remote sensing technology.

In recent years, major energy companies are paying more and more attention to the quality of their services. One of the determining factors of electricity supply continuity is regulated forest cleaning for overhead transmission lines. Due to the rapid development of geoinformation technologies, on-line monitoring of high-voltage transmission lines, including essential specifications has become possible.

\section{Geoinformation Model}

GIS design presupposes the object-oriented development of GIS layers would be maximal informative in descrtibing this or that desired object.

${ }^{1}$ Corresponding author: ikonna@tpu.ru

This is an Open Access article distributed under the terms of the Creative Commons Attribution License 4.0, which permits unrestricted use, distribution, and reproduction in any medium, provided the original work is properly cited. 
In our case, the object was $35 \mathrm{kV}$ electricity transmision line (further, $\mathrm{HV}$ line). An electronic database was designed for the HV line "Turuntaevo-Zarya" [3]. All layers and attribute data were designed within the program QGIS and embraced the following operation steps.

First and foremost, geoinformation basis was selected from the existing built-in QGIS module, i.e. satellite image Bing and OpenStreetMap. Upon the importation of desired down-uploading files, the geodesic survey data proved to be sufficiently accurate with permissible error (PE), i.e. accordingly, the "Turuntaevo-Zarya" right-of-way precisely coincides with its present location (Figure 1).

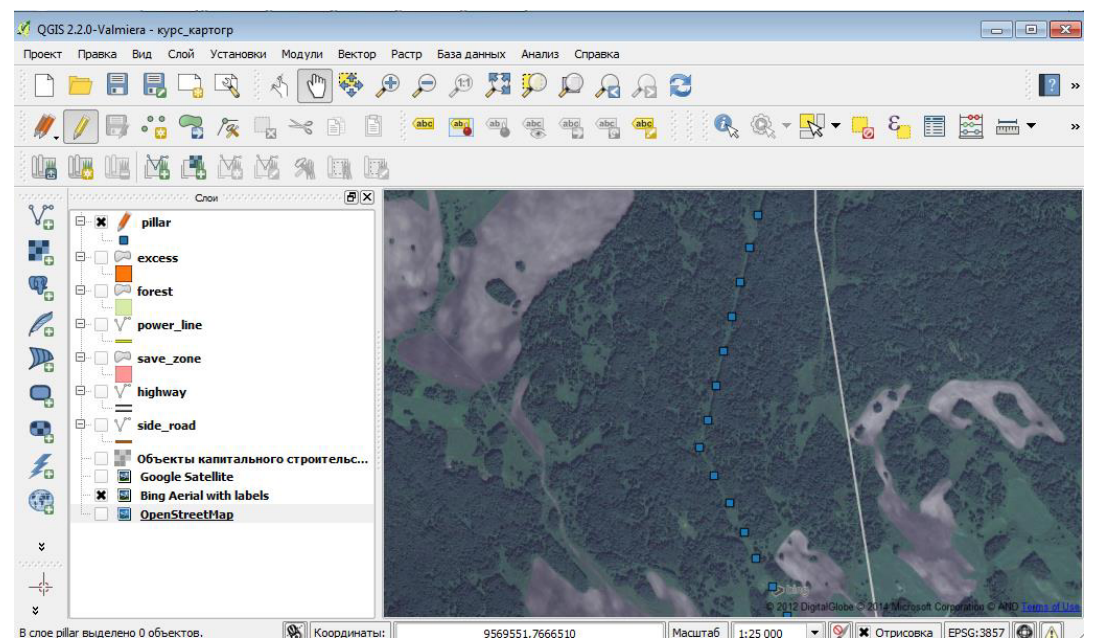

Figure 1. Development of «pillar» layer for "Turuntaevo-Zarya" HV line, superimposing it on BingMap basis.

For improved processing and measurement of the total HV line length, a «power line» layer was designed. The specified attribute «voltage» characterizing the $35 \mathrm{kV}$ HV line was selected from power line property Table (Figure 2).

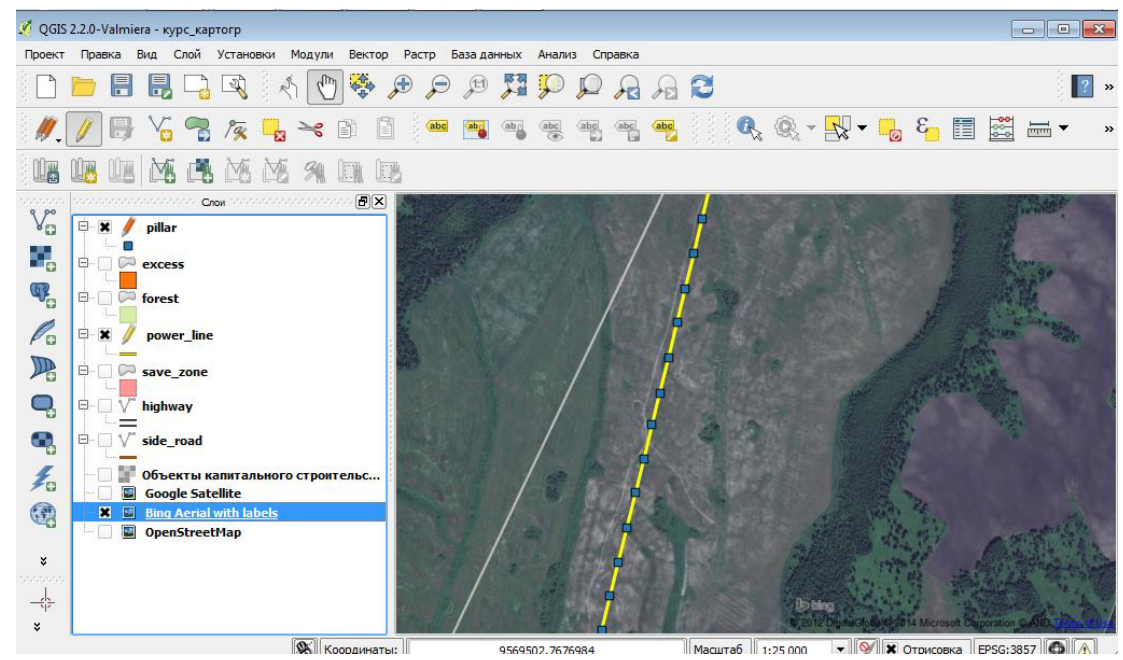

Figure 2. Designing «power line» layer for "Turuntaevo-Zarya" HV line.

The next step was plotting the fenced-off areas, in accordance with State Standard 12.1.05190: Occupational Safety Standards [4]. This area for the $35 \mathrm{kV}$ line is 20 meters (Figure 3). 


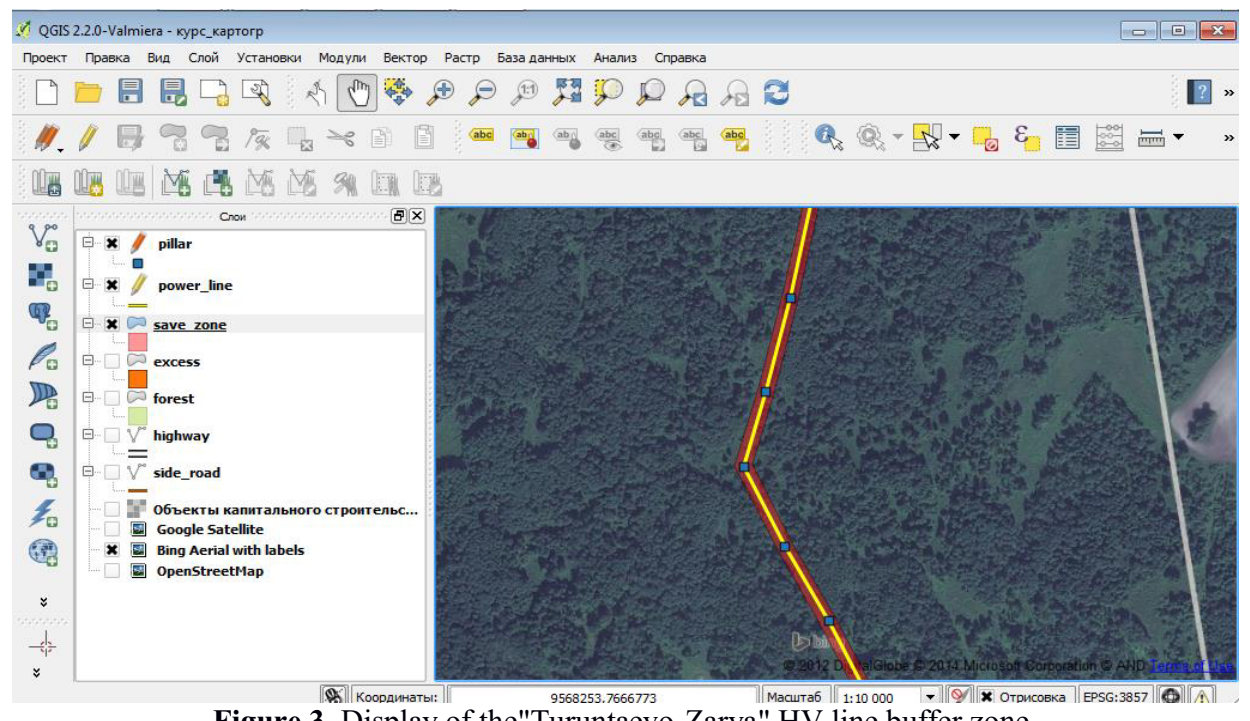

Figure 3. Display of the"Turuntaevo-Zarya" HV line buffer zone.

The next operation step included the delineation of the forest area and the identification of tree species composition within the HV line zone (Figure 4).

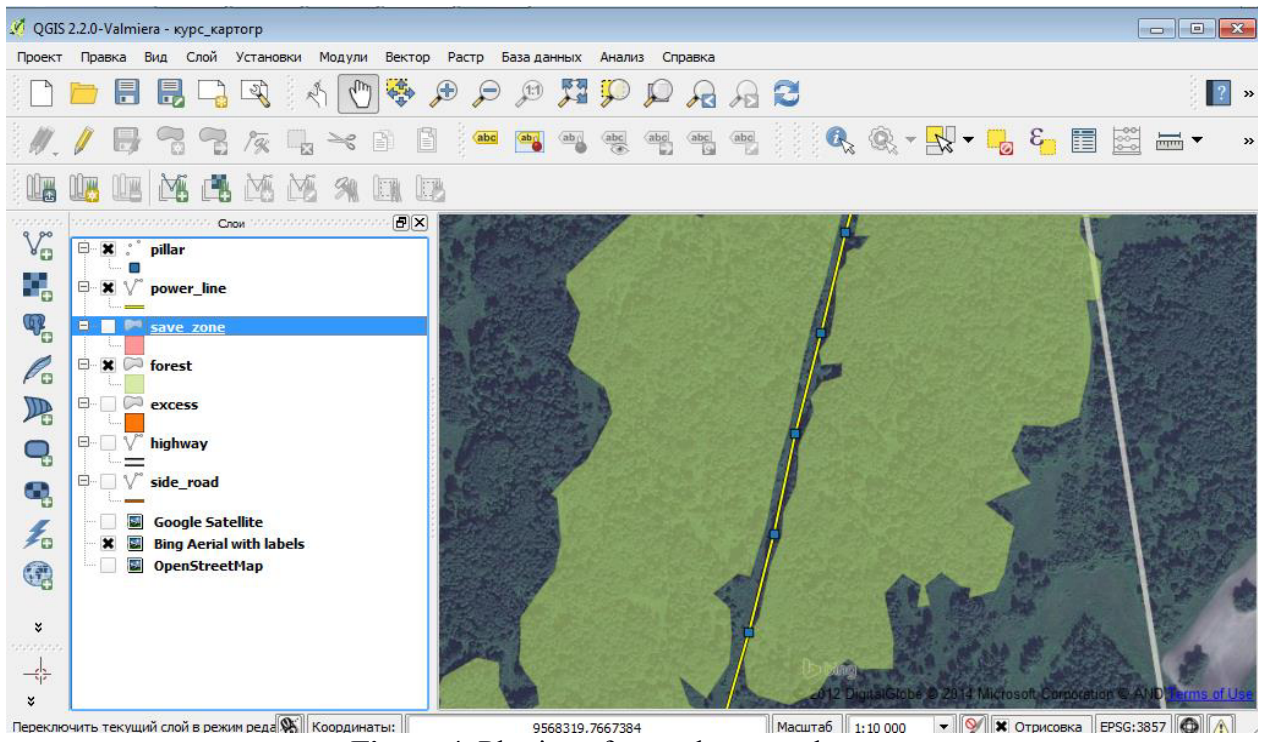

Figure 4. Plotting «forest» layer on the map.

This plotted layer includes the forest layer and buffer zone. It should be noted that in some locations, one layer superimposes on another layer. In our case, the investigated HV line revealed 37 violations (Figure 5). These areas can be considered as high risk zones -loss of electrical connection (i.e. broken power lines) are usually unavoidable as a result of falling trees. Therefore, it is necessary to expand the forest clearing in these areas to established norms. 


\section{MATEC Web of Conferences}

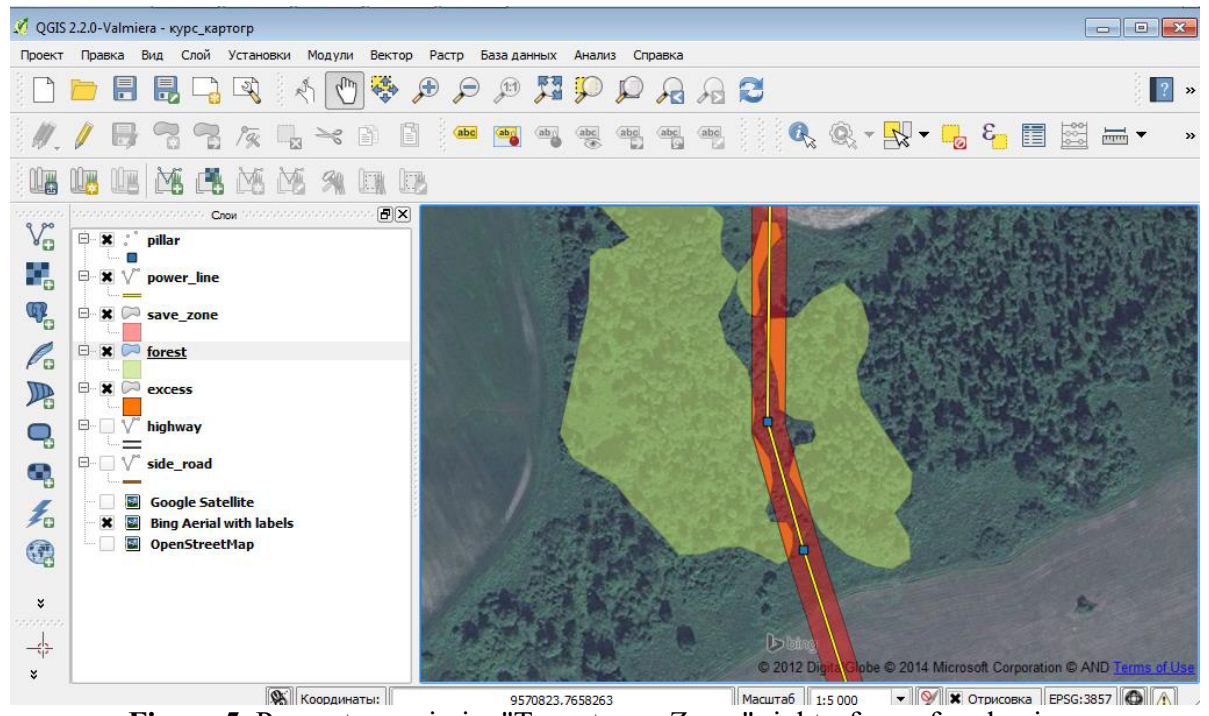

Figure 5. Power transmission"Turuntaevo-Zarya" right-of-way for clearing.

The most dangerous zones were identified and a tributary layer («road») was designed, displaying the closest route to the possible emergency place (Figure 6).

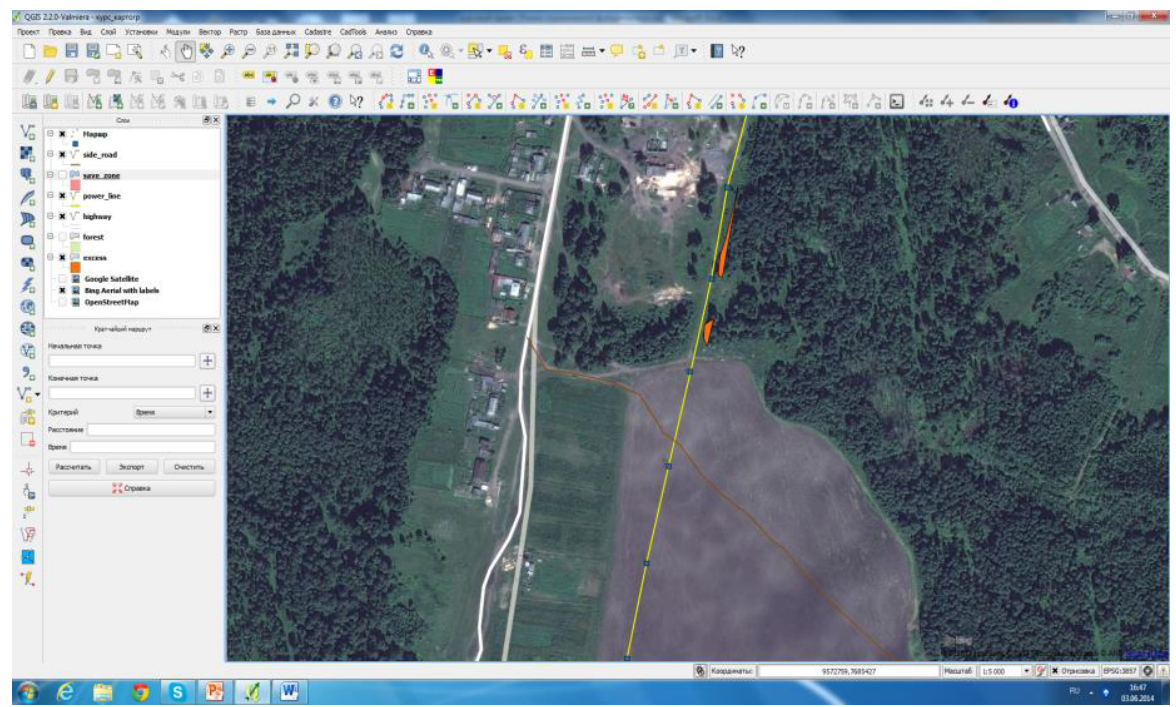

Figure 6. Plotting road network to transmission line "Turuntaevo-Zarya".

\section{Research results}

As a result of geoinformation database processing based on previous geodestic survey data "Turuntaevo-Zarya" 3540 pillars were plotted [5]. In accordance with established regulations the buffer zone of above-mentioned HV line was plotted. The forest road of studied object was analyzed and then relevant layer as plotted. Further, the following aspects were described and determined: regulatory violations, HV line road width, number of recommended clearing sites, as well as plotted tributary road network layer to clearance sites. 


\section{Conclusion}

It should be noted that such an electronic geoportal database is not only informative, timeconsuming, but also economic. The road clearing near HV lines minimizes the number of accidents occurring during power line breakage as a resdult of fallen trees. Precise calculations will ensure balanced deforestation. Ultimately, this electronic database would provide a fairly wide application range.

The following group of people could be interested in the application of such a geoinformation system [5]:

- energy companies (to exclude overhead transmission line accidents and minimize all relevant risks);

- public municipalities (to control unscrupulous suppliers of electricity);

- forestry ( to control timber land holding around HV line areas);

- physical entities (to have free access to the integral part of the server information).

\section{Acknowledgement}

This research was conducted within the framework of the Commerical Contract №2-502/14y.

\section{References}

1. O poryadke ustanovleniya ohrannyih zon ob'ektov elektrosetevogo hozyaystva i osobyih usloviy ispolzovaniya zemelnyih uchastkov, raspolozhennyih $\mathrm{v}$ granitsah takih zon: Postanovlenie Pravitelstva RF ot 24 fevralya 2009 g. N 160 // Internet-portal "Rossiyskoy Gazetyi", 2.09. 2013

2. Official site of JSC "Russian network." - [Electronic resource]. - Mode of access: http://www.rusgrids.com/. - (Date of application: 08.08.2014).

3. State Standard 12.1.051-90. SSBT. Electrical. Safety distances in the buffer zone lines with a voltage above $1000 \mathrm{~V}$.

4. The official website of "Tomsk Distribution Company." - [Electronic resource]. - Mode of access: http://trk.tom.ru/. - (Date of application: 08.08.2014).

5. Vaysblat N.E., GIS kak instrument monitoringa ob'ektov energetiki / N.E. Vaysblat, I.S. Peremitin, K.V. Ikonnikova // Problemyi geologii i osvoeniya nedr: sb. trudov. - Tomsk, 2014. S. 597-600.

6. Sabine Timpf (1998) Map cube model - a model for multi-scale data. 8th International Symposium on Spatial Data Handling (SDH '98) in Vancouver, Canada, 1998. Im Tagungsband eds. K. Thomas und Nicholas Chrisman, International Geographical Union, P. 190-201 